\title{
5. THERMAL CONSTRAINTS ON THE CÔTE D'IVOIRE-GHANA TRANSFORM MARGIN: EVIDENCE FROM APATITE FISSION TRACKS ${ }^{1}$
}

\author{
Jean-Pierre Bouillin, ${ }^{2}$ Gérard Poupeau, ${ }^{2}$ Christophe Basile, ${ }^{2}$ Erika Labrin, ${ }^{2}$ and Jean Mascle ${ }^{3}$
}

\begin{abstract}
Fission-track data obtained on apatite grains from Early Cretaceous sequences from Ocean Drilling Program Leg 159 drill sites and from deep dives sampling along the Côte d'Ivoire-Ghana Marginal Ridge have been used to assess the thermal history of the Côte d'Ivoire-Ghana Transform Margin.

Measurements demonstrate that all the apatite grains were heated above $120^{\circ} \mathrm{C}$ and cooled quickly during the Cretaceous. Apatite fission-track dating are distributed into three groups:

1. A group, characterized by ages ranging $\sim 110 \mathrm{Ma}$, has been only observed on Leg 159 samples. These apatites were found either in the deepest drilled strata, which were heated above $120^{\circ} \mathrm{C}$ as also indicated by hydrothermalism evidences, or in Upper Cretaceous dated strata. In the second case, the apatites are obviously reworked. We believe that the thermal event, postdated by the 110-Ma cooling age, would have been generated by mechanical frictions along an intracontinental transform, active between the African and Brazilian parting basement. The Lower Cretaceous heated formations would subsequently have been locally eroded, to the south and/or the west of the Leg 159 sites. The eroded and reworked material, including 110-Ma apatite grains, would have been then redeposited within the Upper Cretaceous sediments.

2. A group of samples, whose ages are centered $\sim 90 \mathrm{Ma}$, characterize both drilled sediments and slope outcrops. We tentatively explain this new thermal event by a second discontinuous hydrothermal episode, which may have occurred up to Turonian times, along the southward-shifted active transform.

3. Cooling ages between 80 and $70 \mathrm{Ma}$, apparently restricted within the central and western part of the Côte d'Ivoire-Ghana Marginal Ridge, may postdate a new localized heating, which we tentatively interpret as a consequence of a contact between the transform margin and a southern passing oceanic accretionary center.
\end{abstract}

\section{INTRODUCTION}

The Côte d'Ivoire-Ghana (CIG) Transform Margin can be viewed as a typical fossil transform margin (Mascle and Blarez, 1987; Basile et al., 1992, 1993), which originated from the equatorial and the South Atlantic opening (Mascle, 1976; Mascle et al., 1988).

The main morphostructural feature of the CIG Transform Margin is a $130-\mathrm{km}$-long, east-northeast-south-southwest trending marginal ridge, the Côte d'Ivoire-Ghana Marginal Ridge (CIGMR), which constitutes a structural boundary between the Gulf of Guinea oceanic abyssal plain to the south and the rifted Deep Côte d'Ivoire Basin to the north (Figs. 1,2). Within this area previous seismic data have allowed the recognition of five distinct seismic units (Blarez et al., 1987; Basile et al., 1989; Popoff et al., 1989; Basile et al., 1993). These units were reached and sampled during Leg 159 (Mascle, Lohmann, Clift, et al., 1996).

The lowermost unit (seismic Unit A) extends below a major unconformity and has been interpreted as representative of Early Cretaceous synrift sequences deposited during the Côte-d'Ivoire basin rifting (Mascle et al., 1988). This unit outcrops along the CIGMR southern slope and was sampled during 12 dives performed during the Equanaute survey (Mascle et al., 1993; Mascle, 1994). During Leg 159, seismic Unit A was drilled and tentatively correlated with lithologic Unit V or Subunit VB, depending on the hole (Shipboard Scientific Party, 1996c, 1996e). It appears chiefly to be made of alternating sandstones, siltstones, and silty claystones characteristic of subaerial, deltaic, and lacustrine environments. This sequence is barren

${ }^{1}$ Mascle, J., Lohmann, G.P., and Moullade, M. (Eds.), 1998. Proc. ODP, Sci. Results, 159: College Station, TX (Ocean Drilling Program).

${ }^{2}$ UPRES-A5025 CNRS Laboratoire de Géodynamique des Chaînes Alpines, Université de Grenoble-I, 15 rue Gignoux, F38031 Grenoble Cedex, France.

bouillin@ujf-grenoble.fr

${ }^{3}$ Geosciences-Azur, Laboratoire de Geodynamique sous-marine, BP 48, F06230 Villefranche/Mer, France. of microfossils. The first well-dated formation is of late Albian age and also consists of siliciclastics, but with minor intercalations of micritic carbonate. Unit A is unconformably covered by Late Cretaceous carbonates and Cenozoic deposits.

Apatite and zircon fission-track studies of samples recovered during Equanaute dives were previously performed and published (Bouillin et al., 1994, 1997). We present here fission-track ages obtained on apatites from Leg 159, and we attempt to assess the thermal history of the CIG Transform Margin on the basis of fission-track data obtained both from Leg 159 and Equanaute samples.

\section{PREVIOUS DATA}

Prior to Leg 159, fission-track data had already been obtained on six samples from the CIGMR. These samples had been collected in situ through four dives along the CIGMR southern slope during the Equanaute survey (Mascle et al., 1994). Apatites and zircons had been dated using the external detector technique (Hurford and Green, 1993), with the following results (Bouillin et al., 1994; Bouillin et al., 1997):

Zircons. Three samples (EN06-5, EN09-4, and EN09-9) provided zircon grains from which fission-tracks indicate ages much older than the Cretaceous depositional age of the sediments from which they were collected. These data have been taken as evidence that the temperature needed for total track annealing was never reached in these rocks. Following Yamada et al. (1995), such a temperature can be estimated between $320^{\circ} \pm 60^{\circ} \mathrm{C}$ and $390^{\circ} \pm 50^{\circ} \mathrm{C}$. Therefore, the zircon fission-track data provide an upper limit for the temperature attained by the sediments outcropping along the southern slope of the marginal ridge.

Apatites. Apatites from six samples were dated by fission tracks. Three of them (EN 09-2, EN 09-4, and EN 09-9) were sampled at different depths (between 3904 and 2675 meters below sea level) along the same bathymetric profile (dive EN 09), just south of Sites 959 and 
Figure 1. Bathymetric map of the Côte d'Ivoire-Ghana Marginal Ridge and surrounding areas. Location and apatite fission-track ages of the samples shown in circles. Bathymetric interval $=250 \mathrm{~m}$.
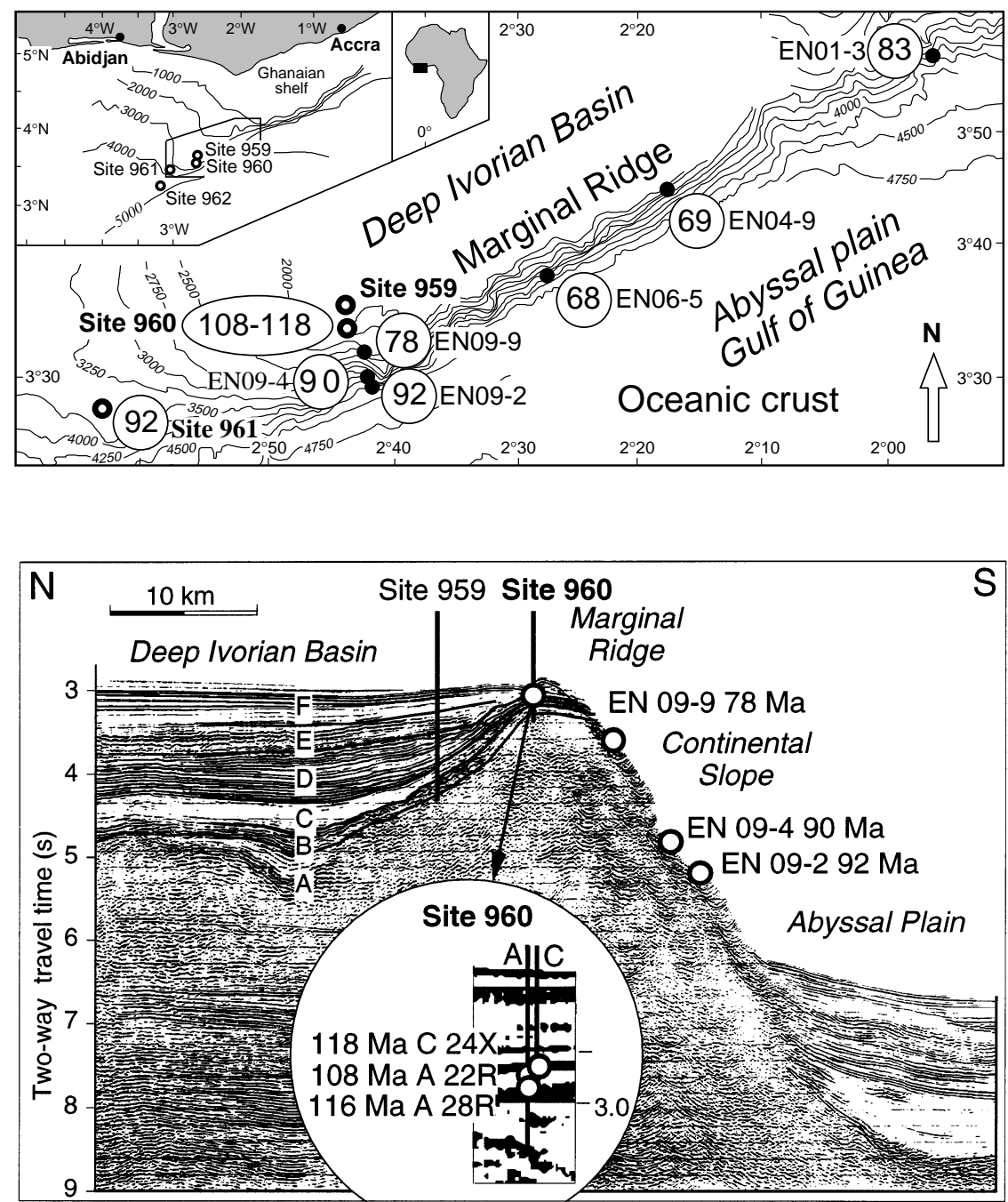

Figure 2. Migrated multilateral seismic section from Line MT02 across the Deep Ivorian Basin, the Marginal Ridge, and the abyssal plain (Lamarche et al., 1997). Locations of Sites 959 and 960 and of samples taken on the seafloor during the EN 09 Equanaute dive are indicated. Main seismic units (A through F) are shown (Basile et al., 1996). Enlargement: Line MT02. could be obtained from such a small data set, results are consistent with Equanaute data and with other Leg 159 fission-track data (Clift et al., Chap. 4, this volume).

Apatites of the four composite samples, from Sites 960 and 961, were dated with the external detector technique using the same experimental procedures as for our Equanaute samples (Bouillin et al., 1997). The results are reported in Table 1. At Site 960, two samples present rather well-defined Early Cretaceous ages of respectively 108 $\pm 11 \mathrm{Ma}$ and $118 \pm 8 \mathrm{Ma}$; the unique crystal, which could be dated from another sample gives an apparently concordant, albeit very imprecise, age of $116 \pm 37 \mathrm{Ma}$. This overall fission-track age range is about the same as that obtained by Clift et al. (Chap. 4, this volume) on apatites from Site 959.

\section{DISCUSSION AND INTERPRETATION}

We received 18 samples from Sites 959, 960, 961, and 962, re-
pectively (Shipboard Scientific Party, 1966b, 1996c, 1966d, 1996e). Based on their location in the drilled column (Fig. 3), the samples were pooled for mineral separation into 10 composite samples: 159959D-76R and 77R, 159-960A-20R, 22R, 28R, 29R, and 46R, 159960C-24X, 159-961B-18R, and 159-962D-6R and 18R. After crushing and conventional heavy liquids/magnetic separation procedures, very few apatite grains were found in only four samples, allowing us to only date from one to four crystals in each separate and excluding the possibility of confined fission-track lengths measurements. However, in spite of the very limited fission-track information, which

960 (Fig. 2). The other samples came from various depths along the The apatite fission-track ages range from $92 \pm 7 \mathrm{Ma}$ to $68 \pm 9 \mathrm{Ma}$ all grains in each sample belong to the same age population (Bouillin et al., 1997). The mean confined track lengths vary in these samples between $\sim 120^{\circ}$ and $60^{\circ} \mathrm{C}$. This was interpreted as the result of a postCretaceous cooling.

\section{METHODS AND RESULTS}

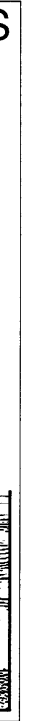

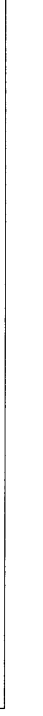

. 
Table 1. Fission-track analytical data.

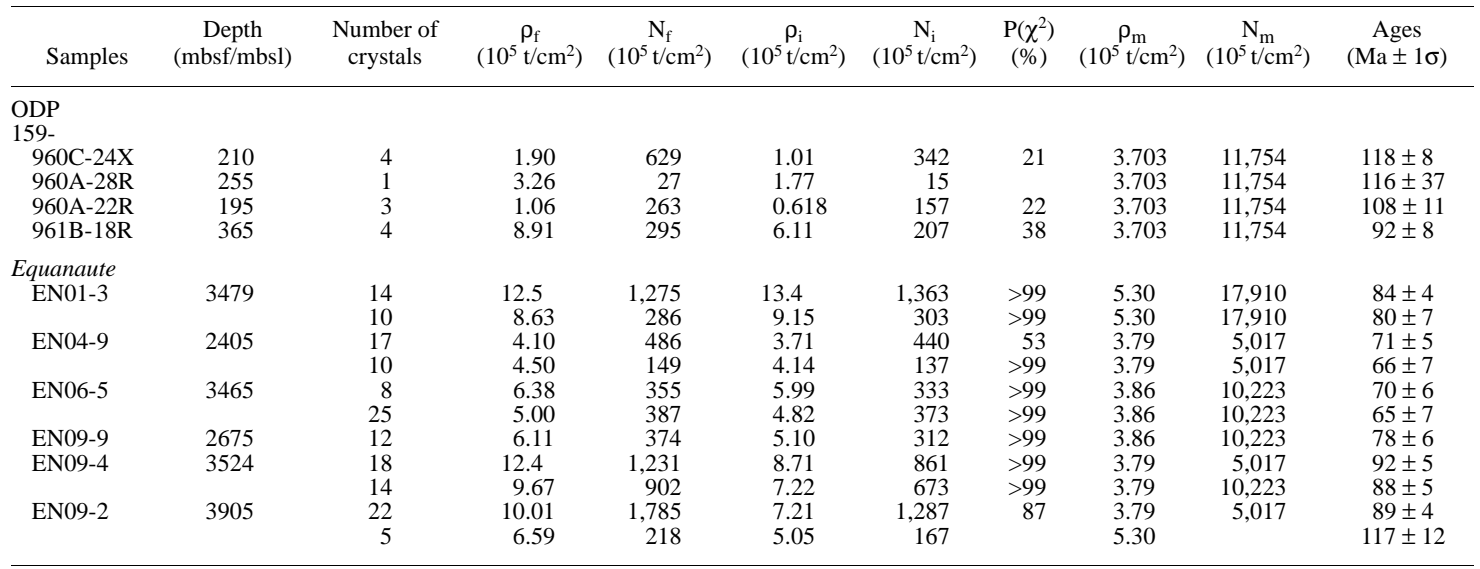

Notes: Depth of ODP samples is measured in meters below the seafloor (mbsf). Equanaute samples were collected on the seafloor, and their depth is measured in meters below sea level (mbsl). Water depths are $2048 \mathrm{~m}$ for Hole $960 \mathrm{~A}, 2035 \mathrm{~m}$ for $960 \mathrm{C}$, and $3292 \mathrm{~m}$ for $961 \mathrm{~B}$. $\mathrm{N}_{\mathrm{f}}$ and $\mathrm{N}_{\mathrm{i}}$ are, respectively, the total number of fossil (f) and induced (i) tracks counted; $\rho_{\mathrm{f}}$ and $\rho_{\mathrm{i}}$, the fossil and induced track densities in apatites and their kapton external detectors; $\rho_{\mathrm{m}}=$ the induced track densities in the kapton detectors associated with NIST neutron glass monitors 962 . $\mathrm{P}\left(\chi^{2}\right)=$ the probability of obtaining a $\chi^{2}$ value for $n-1$ degrees of freedom. As all samples passed the test at a $95 \%$ confidence level with $\mathrm{P}\left(\chi^{2}\right)>$ $5 \%$, ages were calculated using a pooled statistics (Green 1981). The precision on ages was calculated following the conventional method of Green $(1981)$ as st/t $=\left(1 / \mathrm{N}_{\mathrm{f}}+1 / \mathrm{N}_{\mathrm{i}}+\right.$ $\left.1 / \mathrm{N}_{\mathrm{m}}\right)^{1 / 2}$. The ages of ODP samples were calculated with a zeta value of $339 \pm 12$. Equanaute data are from Bouillin et al. (1997). For these samples, except EN09-09, apatite tracks were counted twice by different observers with a geometric factor $\mathrm{g}=0.5$ : EL (first line) and NS (second line) for EN01-3, EL and NS for EN04-9, EL and FG for EN06-5, EL twice for EN09-4 and EN09-2. Zeta values: $321 \pm 7$ for EL, $321 \pm 4$ for NS, and $322 \pm 25$ for FG. Weighted ages for these samples are respectively $83 \pm 7$ Ma, $69 \pm 8$ Ma, $68 \pm 9$ $\mathrm{Ma}, 90 \pm 7 \mathrm{Ma}$ and $92 \pm 7 \mathrm{Ma}( \pm 2 \sigma)$

2. The second group, with an age centered $\sim 90 \mathrm{Ma}$, characterizes samples from both the drilled holes and the southern ridge slope outcrops.

3. The other ages, between 80 and $70 \mathrm{Ma}$, appear restricted to samples retrieved from the slope, a few tens of kilometers eastnortheast from ODP sites.

In addition, for those samples where track lengths could be measured (Bouillin et al., 1997; Clift et al., Chap. 4, this volume), mean confined lengths values are always $>14 \mu \mathrm{m}$, which implies a fast cooling through the apatite partial annealing zone $\left(\sim 120^{\circ} \mathrm{C}-60^{\circ} \mathrm{C}\right)$. Finally, considering the track lengths distributions and the homogeneity of fission track ages (all samples pass the $\chi^{2}$ test), we consider (see below) the last cooling below $\sim 120^{\circ} \mathrm{C}$ occurred in situ in the CIGMR.

The proposed interpretation of the fission-track ages takes into account stratigraphic and thermal data also determined from samples from Leg 159 holes.

\section{Samples from the Deepest and Undated Siliciclastic Sequence (Lithologic Unit V)}

The deepest drilled strata lie below an unconformity interpreted as the synrift or syntransform unconformity (Mascle, Lohmann, Clift, et al., 1996). This lithologic unit, tentatively correlated to seismic formation A (Basile et al., 1996), was also sampled along the southern CIGMR slope (Benkhelil et al., 1996). It appears strongly disrupted and shows evidence of hydrothermal circulation illustrated by numerous veins of kaolinite.

We believe that this unit was heated at rather high temperatures: for example, veins of quartz sampled near the bottom of Hole 960A contain fluid inclusions with indications of trapping temperatures $\sim 160^{\circ}-170^{\circ} \mathrm{C}$, according to Lespinasse et al. (Chap. 6, this volume). Such temperatures are consistent with the presence of hydrothermal kaolinite (nacrite, according to Holmes et al., Chap. 7, this volume). Apparently, heating seems to have been stronger along the southern CIGMR slope where rocks correlated with this unit contain chloritic and mica stacks, indicating temperatures between $200^{\circ}$ and $300^{\circ} \mathrm{C}$ (Benkhelil et al., 1996).

We, therefore, conclude that all the apatites reworked in the deeper siliciclastic sedimentary unit (lithologic Unit V) were heated in situ and above $120^{\circ} \mathrm{C}$, the temperature needed for annealing predetritic tracks. We, consequently, believe that apatite fission tracks date the cooling of the rocks that contain these apatites.

Samples EN9, from the slope just south from Sites 959 and 960, provide fission-track ages $\sim 90 \mathrm{Ma}(92 \pm 7 \mathrm{Ma}, 90 \pm 7 \mathrm{Ma}$, and $78 \pm$ $12 \mathrm{Ma}$ ), whereas Sample 159-961B-18R, which also originates from this unit, provides an age of $92 \pm 8 \mathrm{Ma}$. Thus, $90 \mathrm{Ma}$ appears as a minimum age for lithologic Unit $\mathrm{V}$.

\section{Samples of the Late Cretaceous Sequences (Lithologic Units IV and III)}

Core 159-960C-24X is stratigraphically located between cores respectively dated from Turonian and from Coniacian-Santonian (Shipboard Scientific Party, 1966c). Although the analyzed sample belongs obviously to the Late Cretaceous, its apatite grains provide a fission-track age of $118 \pm 8 \mathrm{Ma}$; this substantiates the hypothesis that apatite has necessarily been reworked as proposed for other samples by Clift et al. (Chap. 4, this volume).

Comparably, apatite grains from Samples 159-960A-28R and 22R, still micropaleontologically undated, but likely Late Cretaceous in age (according to their carbonate contents), are dated respectively at $116 \pm 37 \mathrm{Ma}$ and at $108 \pm 11 \mathrm{Ma}$, and are thus also probably reworked.

We believe that 110-Ma-old apatites indicate that a cooling episode occurred just after heating processes, which should have recorded a major geodynamic event. This event may tentatively be coeval with the rifting evolution of the Côte d'Ivoire Basin as recognized on the conjugate Brazilian Margin (Zalan et al., 1985; Costa et al., 1990). However, at Site 962, the main unconformity characterizes the top of a well-dated late Albian formation (lithologic Unit III of Hole 962, Shipboard Scientific Party, 1996e, p. 263), which appears strongly deformed. Because at Sites 959 through 961 marine Albian formations are missing or very thin, we suspect that the deformed 


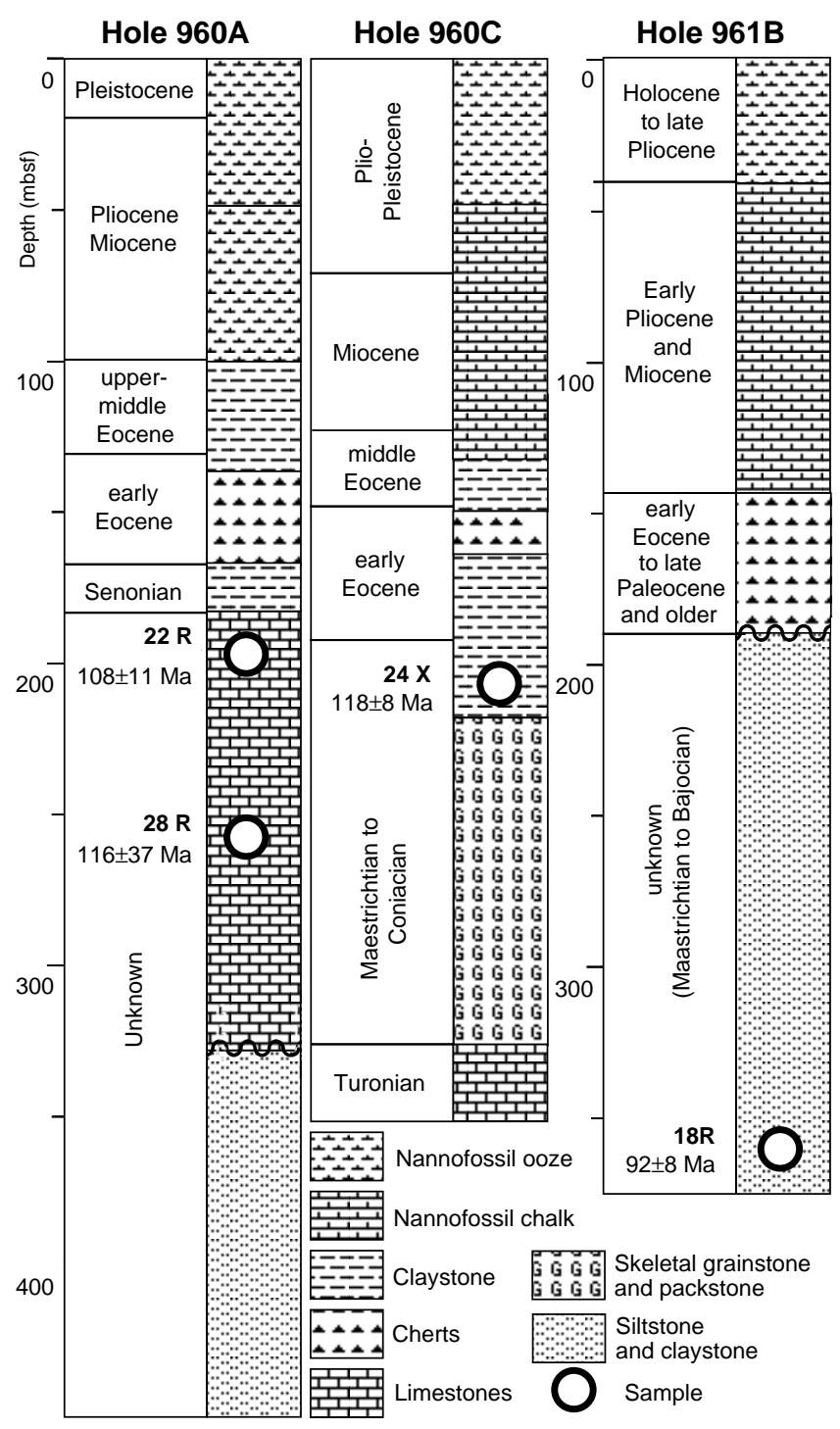

Figure 3. Schematic stratigraphic log of Holes 960A, 960C, and 961B.

Albian sequences from Site 962 are coeval from the syntransform margin stage and rest over a deeper break-up unconformity. At Sites 959-961, the break-up unconformity may have been eroded or may be merging with the post-Albian unconformity.

Several hypotheses can be proposed to explain an Aptian heating event. The first consists of a simple sedimentary burial; according to standard geothermal gradient of $30^{\circ} \mathrm{C} / \mathrm{km}$, such a mechanism would imply that apatites were, by that time, covered by more than $4 \mathrm{~km}$ of sediments, which would have been eroded before the Albian. Moreover, if correct, parts of the Lower Cretaceous units would remain at temperatures between $60^{\circ}$ and $120^{\circ} \mathrm{C}$, in the track partial annealing zone. Short, confined fission tracks, however, are neither observed within the apatites of siliciclastic Subunit VB nor in the apatites reworked in Upper Cretaceous sequences analyzed by Clift et al. (Chap. 4, this volume). For this reason, we favor a second hypothesis in which heating would be mainly generated by mechanical friction within an intracontinental fault acting between the African and Brazilian basements, and also possibly a consequence of continental thinning (Mascle and Blarez, 1987; Todd and Keen, 1989; Lorenzo et al., 1991). Heat may thus have been transferred by hydrothermal circulation, potentially to the former seafloor. The cores from the si- liciclastic Subunit VB effectively display evidence of a moderate to relatively high degree of hydrothermalism (veins of kaolinite, hightemperature generated fluid inclusions, etc.). Such a hypothesis may also explain a quick cooling of the apatites that would have resulted from a sudden break in hydrothermal circulation induced by a shift toward the south of the active fault zone, as inferred by Shipboard Scientific Party (1996a, p. 301).

It is likely that, in Albian times and during the Late Cretaceous, formations bearing apatite cooled at $110 \mathrm{Ma}$, were eroded and led to the deposition of detritic crystals in the sedimentary strata now outcropping along the southern border of the Deep Côte d'Ivoire basin (Samples 159-960C-24X and 159-960A-22R and 28R; see also Clift et al., Chap. 4, this volume). These eroded formations belonged probably to lithologic Subunit VB. We propose that these Lower Cretaceous deposits were uplifted and eroded during Cretaceous time to the south and/or to the east of the present CIGMR. Because we did not find, within the sediments of the Deep Côte d'Ivoire basin, any apatite crystals indicating fission-track ages older than Cretaceous, we suspect that the eroded domain was, by that time, disconnected from the Brazilian basement by a marine basin since Turonian-Coniacian times and possibly before that time.

Along the western CIGMR several samples, EN09-2 and EN09-3 (along the southern slope) and 159-961B-18R, provided an age $\sim 90$ Ma. Sample EN09-9 yielded an apparently younger, but nevertheless not discordant, age of $78 \pm 24(2 \sigma) \mathrm{Ma}$. All these samples belong to the siliciclastic Subunit VB, which was heated above $120^{\circ} \mathrm{C}$ during the Early Cretaceous. We believe that these ages may relate to a second hydrothermal event occurring near the Cenomanian/Turonian boundary. This heating would have annealed previous fission tracks only within very localized hydrothermal fracturing, and thus, both $110 \mathrm{Ma}$ and $90 \mathrm{Ma}$ ages may coexist in the same formation. Fissiontrack ages at $90 \mathrm{Ma}$ are not found in Upper Cretaceous samples. This tends to indicate that erosion of the CIGMR during the Late Cretaceous may have not reached levels where second hydrothermal circulation occurred.

Finally, ages of cooling ranging between 70 and 80 Ma are observed in the eastern CIGMR; possibly they record a more recent, spacially restricted, track-annealing event triggered by the relative transform motion of the margin along a hot oceanic crust.

\section{IMPLICATIONS FOR THE GEODYNAMIC EVOLUTION}

We have attempted in Figure 4 to incorporate the fission-track data within the framework of a geodynamic scenario for the CIG Transform Margin.

This sketch illustrates five distinct evolutionary stages:

In Stage 1, the African and South American continental crusts are in contact. Crustal stretching, induced by rifting, and friction along an active intracontinental wrench fault zone produce a regional heating. Heat is partly transferred to the surface by hydrothermal circulation. Sometime between the Aptian and Albian a decrease in hydrothermal circulation may be related to the uplift of a proto-CIGMR.

During Stage 2, the thinned continental crust of the future Brazilian margin gets into contact with the African CIGMR. The sharp difference in elevation between the two crusts induces the creation of a steep slope, which cuts across the border of the African plate.

In Stage 3, the newly created oceanic crust, linked to the South American plate, contacts the African margin. At first, the bathymetric step between the two domains appears important. Later on, this difference decreases when a younger and hot oceanic crust is progressively drifting along the African margin. Heat transfers from a relatively hot oceanic to a colder continental crust are likely. Hydrothermal circulation may occur along the active transform fault up to Turonian times. A 90-Ma fission-track age substantiates that cooling 

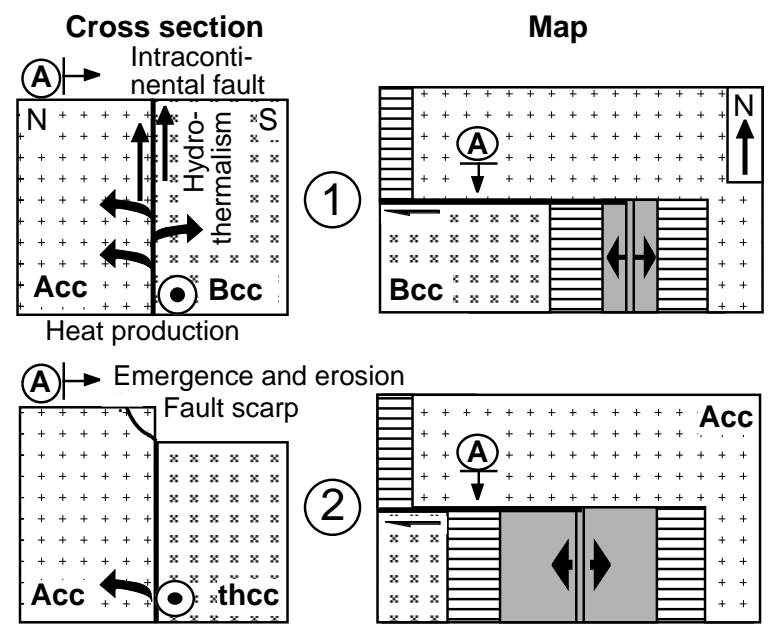

(A) 1 uplift

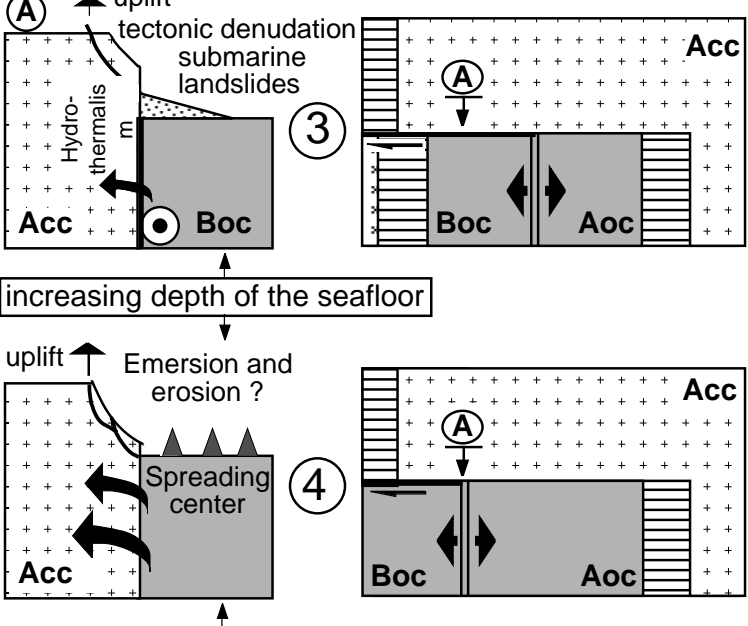

increasing depth of the seafloor

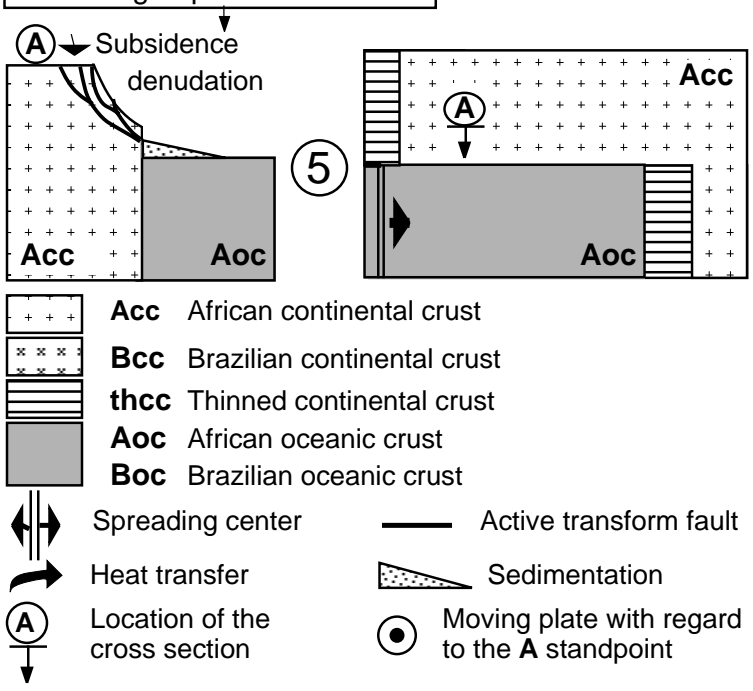

Figure 4. Very schematic evolution of the CIG Transform Margin during the Cretaceous. Left: Cross section cutting the Margin through the arbitrary fixed point A. Right: Sketch map. The African Plate is arbitrarily fixed.

of the Marginal Ridge may have occurred just after its erosion or/and a cessation of hydrothermal activities. Lateral uncovering of the African basement related to faulting and landslides along the transform fault potentially occur. This uncovering may induce a sudden cooling of the southern marginal ridge slope.
In Stage 4, the oceanic accretionary center passes along the transform margin. This leads to a new heating of the CIGMR continental crust and to a new uplift of the feature. The ocean/continent transform fault becomes progressively inactive. Cooling temperatures $\sim 80$ to 70 $\mathrm{Ma}$, as recorded by apatite fission tracks in several areas of the CIGMR southern slope, may be correlated with this last event.

Finally during Stage 5, the African continental and oceanic crusts are in contact. Both are progressively cooling, but the difference in subsidence rate between continental and oceanic crusts tend to initiate a new faulting and landslide episode.

\section{CONCLUSIONS}

Fission-track dating of rocks from the CIGMR southern slope and from Leg 159 holes help to better assess the thermal history of a transform margin such as the Côte d'Ivoire-Ghana Transform Margin.

We show that three thermal events (temperature above $120^{\circ} \mathrm{C}$ ), each followed by fast cooling, successively occurred. An older event, $\sim 110 \mathrm{Ma}$, correlated with hydrothermal circulation, is tentatively explained by intracontinental transform fault activities during Early Cretaceous times, likely before middle Albian. A second event, dated $\sim 90 \mathrm{Ma}$, which appears discontinuous, may have also lead to hydrothermal circulation processes; this episode is tentatively related to the activity of an ocean/continent transform fault. Finally, the apatite fission-track ages $\sim 80-70 \mathrm{Ma}$ indicate a last cooling episode, after a thermal event resulting from a contact between the margin and the passing hot oceanic crust.

\section{ACKNOWLEDGMENTS}

F. Coeur and F. Senebier (Grenoble laboratory) are thanked for their assistance. Financial support of INSU-Geosciences Marines made the sample analyses possible. This manuscript is contribution number 119 of Geosciences-Azur (UMR-CNRS 652).

\section{REFERENCES}

Basile, C., Brun, J.P., and Mascle, J., 1992. Structure et formation de la marge transformante de Côte d'Ivoire-Ghana: apports de la sismique réflexion et de la modélisation analogique. Bull. Soc. Geol. Fr., 163:207216.

Basile, C., Mascle, J., Auroux, C., Bouillin, J.P., Mascle, G., Goncalves de Souza, K., and le Groupe Equamarge, 1989. Une marge transformante type, la marge continentale de Côte d'Ivoire-Ghana: résultats préliminaires de la campagne Equamarge II, mars 88. C. R. Acad. Sci. Ser. 2, 308:997-1004.

Basile, C., Mascle, J., Popoff, M., Bouillin, J.P., and Mascle, G., 1993. The Côte d'Ivoire-Ghana transform margin: a marginal ridge structure deduced from seismic data. Tectonophysics, 222:1-19.

Basile, C., Mascle, J., Sage, F., Lamarche, G., and Pontoise, B., 1996. Precruise and site surveys: a synthesis of marine geological and geophysical data on the Côte d'Ivoire-Ghana Transform Margin. In Mascle, J., Lohmann, G.P., Clift, P.D., et al., Proc. ODP, Init. Repts., 159: College Station, TX (Ocean Drilling Program), 47-60.

Benkhelil, J., Guiraud, M., Mascle, J., Basile, C., Bouillin, J.-P., Mascle, G., and Cousin, M., 1996. Structural record of the Africa/Brazil sliding in the Cretaceous sediments of the Côte d'Ivoire-Ghana transform margin. C.R. Acad. Sci. Ser. 2, 323:73-80.

Blarez, E., Mascle, J., Affaton, P., Robert, C., Herbin, J.P., and Mascle, G., 1987. Géologie de la pente continentale ivoiro-ghanéenne: résultats de dragages de la campagne Equamarge. Bull. Soc. Geol. Fr., 5:877-885.

Bouillin, J.-P, Poupeau, G., Labrin, E., Basile, C., Sabil, N., Mascle, J., Mascle, G., Gillot, F., and Riou, L.,1997. Fission track study of the marginal ridge of the Ivory Coast-Ghana transform margin. Geo-Mar. Lett.

Bouillin, J.P., Poupeau, G., Riou, L., Sabil, N., Basile, C., Mascle, J., Mascle, G., and the Equanaute Scientific Party, 1994. La marge transformante de 
Côte d'Ivoire-Ghana: premières donneés thermo-chronologiques (campagne Equanaute, 1992). C. R. Acad. Sci. Ser. 2, 318:1365-1370.

Costa, I.G., Beltrami, C.V., and Alves, L.E.M., 1990. A evoluçao tectonosedimentar e o habitat do oleo da bacia do Ceara. Bol. Geoci. PETROBRAS, 4:65-74.

Green, P.F., 1981. A new look at statistics in fission-track dating. Nucl. Tracks, 5:77-86.

Hurford, A.J. and Green, P.F., 1993. The zeta calibration of fission track dating. Isotope Geosci., 1:285-317.

Lamarche, G., Basile, C., Mascle, J., and Sage, F., 1997. The Côte d'IvoireGhana transform margin: nature and formation of a Marginal Ridge. Geo-Mar. Lett.

Lorenzo, J.M., Mutter, J.C., Larson, R.L., Buhl, P., Diebold, J.B., Alsop, J., Hopper, J., Falvey, D., Williamson, P., and Brassil, F., 1991. Development of the continent-ocean transform boundary of the southern Exmouth Plateau. Geology, 19:843-846.

Mascle, J., 1976. Le golfe de Guinée: un exemple d'évolution de marge atlantique en cisaillement. Mem. Soc. Geol. Fr., 128.

Mascle, J. (Ed.), 1994, Les marges continentales transformantes ouest-africaines côte d'Ivoire, Ghana, Guinée, Campagne Equanaute ( 3 juin-2 juillet 1992). Ser. Rep. Ocean, 5.

Mascle, J., and Blarez, E., 1987. Evidence for transform margin evolution from the Côte d'Ivoire-Ghana continental margin. Nature, 326:378-381.

Mascle, J., Blarez, E., and Marinho, M., 1988. The shallow structures of the Guinea and Ivory Coast-Ghana transform margins: their bearing on the Equatorial Atlantic Mesozoic evolution. Tectonophysics, 155:193-209.

Mascle, J., Guiraud, M., Basile, C., Benkhelil, J., Bouillin, J.P., Cousin, M., and Mascle, G., 1993. La marge transformante de Côte d'Ivoire-Ghana: premiers résultats de la campagne Equanaute (Juin 1992) [The Côte d'Ivoire-Ghana transform margin: preliminary results from the Equanaute cruise (June 1992)]. C. R. Acad. Sci. Ser. 2, 316:1255-1261.

Mascle, J., Lohmann, G.P., Clift, P.D., and Shipboard Scientific Party, 1996. Introduction. In Mascle, J., Lohmann, G.P., Clift, P.D., et al., Proc. ODP, Init. Repts., 159: College Station, TX (Ocean Drilling Program), 5-16.

Popoff, M., Raillard, S., Mascle, J., Auroux, C., Basile, C., and Equamarge Group, 1989. Analyse d'un segment de marge transformante du Ghana: résultats de la campagne Equamarge II (mars 1988). C. R. Acad. Sci. Ser. 2, 309:481-487.
Shipboard Scientific Party, 1996a. Principal results. In Mascle, J., Lohmann, G.P., Clift, P.D., et al., Proc. ODP, Init. Repts., 159: College Station, TX (Ocean Drilling Program), 297-314.

, 1996b. Site 959. In Mascle, J., Lohmann, G.P., Clift, P.D., et al., Proc. ODP, Init. Repts., 159: College Station, TX (Ocean Drilling Program), 65-150.

, 1996c. Site 960. In Mascle, J., Lohmann, G.P., Clift, P.D., et al., Proc. ODP, Init. Repts., 159: College Station, TX (Ocean Drilling Program), 151-215.

, 1996d. Site 961. In Mascle, J., Lohmann, G.P., Clift, P.D., et al., Proc. ODP, Init. Repts., 159: College Station, TX (Ocean Drilling Program), 217-249.

1996e. Site 962. In Mascle, J., Lohmann, G.P., Clift, P.D., et al., Proc. ODP, Init. Repts., 159: College Station, TX (Ocean Drilling Program), 251-294.

Todd, B.J., and Keen, C.E., 1989. Temperature effects and their geological consequences at transform margins. Can. J. Earth Sci., 26:2591-2603.

Yamada, R., Tagami, T., Nishimura, S., and Ito, H., 1995. Annealing kinetics of fission tracks in zircon: an experimental study. Chem. Geol., 122:249258.

Zalan, P.V., Nelson, E.P., Warme, J.E., and Davis, T.L., 1985. The Piaui basin: rifting and wrenching in an Equatorial Atlantic transform basin. In Biddle, K.T., and Christie-Blick, N. (Eds.), Strike-slip Deformation, Basin Formation, and Sedimentation. Spec. Publ.-Soc. Econ. Paleontol. Mineral., 37:143-158.

Date of initial receipt: 24 September 1996

Date of acceptance: 15 April 1997

Ms 159SR-047 